\title{
Graph of Violence over Women in West Bengal\& India: the possible way out
}

\author{
Debashri Banerjee \\ Assistant Professor, C.R.P. College, West Bengal
}

\begin{abstract}
Women Are Thought To Be The Weakest Species Upon The Earth. They Have To Live Within The Rules Of The Patriarchal Society Where The Patriarchs Are The Head Of Not Only The Family But Also Of The Society. Violence Over Them Seems To Be The Increasing Trend Of The Society. The Increase In Crimes Against Women Is Very Alarming Today. These Crimes Include Rape, Gang-Rape, Marital Rape, Acid Attacks, Molestation, Eve-Teasing, Dowry Death, Female Feticide, Sexual Harassments, Sexual Comments, Domestic Violence, Forced Sex And Many More. West Bengal Is Considered As The Province With Huge Population Density A Little More Than 900 People Per Square Km. Here The Ratio Of Female Population Along With Their Growth Of Literacy, Their Conditions Of Livelihood, Work Culture, Maternal Mortality Ratio Etc Has To Be Searched Thoroughly In This Present Article. Many Years Ago Simone De Beauvoir, In Her Book Named Thesecondsex, Claimed That A Woman Is Nothing But Her Womb. Hence They Are Symbolically Related With Their Reproduction System. Does The Picture Changed At All After So Many Years Is The Main Focus Of Our Discussion Of This Dissertation. The Alarming Fact Is That It Does Not Change At All.

However We Should Not Leave The Discussion Here. We Should Discover The Possible Way Out From This Situation. It Is Easy To Cite The Problem But Not Easy To Discover The Possible Way Out. Our Task Will Be To Search For The Solution Instead Of Just Referring To The Questions.
\end{abstract}

Keyword: Rape, Gang-Rape, Marital Rape, Molestation, Dowry Death, Crimes Against Women, Violence.

\section{INTRODUCTION}

West Bengal Is Considered As The Province With Huge Population Density A Little More Than 900 People Per Square Km. Here The Ratio Of Female Population Along With Their Growth Of Literacy, Their Conditions Of Livelihood, Work Culture, Maternal Mortality Ratio Etc Has To Be Searched Thoroughly In This Present Article. Many Years Ago Simone De Beauvoir, In Her Book Named Thesecondsex, Claimed That The Definition Of Woman Is Very Tricky. Some Critics Claim That A Woman Is Nothing But Her Womb. According To St. Thomas A Woman Is An Incomplete Man Who Exists Devoid Of Manhood. In The View Of Monsieur Benda Woman Is Just The Other Sex Than Man. Most Of The Critics Relate The Women Symbolically With Their Reproduction System. Does The Picture Changed At All After So Many Years Is The Main Focus Of Our Discussion Of This Dissertation.

Now Let Us Start With The Table 1 Where The Literacy Ratio Along With Working Ratio Of The Men And Women. Here The Ratio Of Population Growth (1991-2001) And Population Density (2001) Is Clearly Demonstrated.

\begin{tabular}{|c|c|c|c|c|c|c|c|c|c|c|}
\hline \multirow{3}{*}{ State } & \multirow{3}{*}{$\begin{array}{c}\text { Popl. } \\
\text { Gro } \\
\text { wth } \\
\% \\
\text { P.A. } \\
1991 \\
- \\
2001\end{array}$} & \multirow{3}{*}{$\begin{array}{c}\text { Popl. } \\
\text { Densit } \\
\text { y } \\
\text { Sq } \\
\text { Km } \\
2001\end{array}$} & \multirow{3}{*}{$\begin{array}{c}\text { Urban } \\
\text { Popl. } \\
\% \\
2001\end{array}$} & \multirow{3}{*}{$\begin{array}{c}\text { S e x } \\
\text { Rati } \\
\text { o } \\
\%\end{array}$} & \multirow{3}{*}{$\begin{array}{c}\text { Infant } \\
\text { Mort } \\
\text { ality } \\
\text { Rate } \\
1996\end{array}$} & \multirow{3}{*}{$\begin{array}{c}\text { Maternal } \\
\text { Mort } \\
\text { ality } \\
\text { Rate } \\
\mathbf{1 9 9 8}\end{array}$} & \multirow{2}{*}{\multicolumn{2}{|c|}{$\begin{array}{c}\text { L i t e r a t e } \\
\text { Population } \\
\% 2001\end{array}$}} & \multirow{2}{*}{\multicolumn{2}{|c|}{ Working Popl. \% 2001}} \\
\hline & & & & & & & & & & \\
\hline & & & & & & & Men & Women & Men & Women \\
\hline$(1)$ & $(2)$ & $(3)$ & $(4)$ & $(5)$ & $(6)$ & $(7)$ & $(8)$ & $(9)$ & $(10)$ & $\left(\begin{array}{ll}1 & 1\end{array}\right)$ \\
\hline Assam & 1.9 & $\begin{array}{lll}3 & 4 & 0 \\
\end{array}$ & 19.6 & 932 & 74 & 409 & 71.9 & 56.0 & 49.9 & 20.8 \\
\hline $\begin{array}{c}\text { Andhra } \\
\text { Pra } \\
\text { des } \\
\mathrm{h}\end{array}$ & 1.4 & 275 & 27.1 & 972 & 6 & 159 & 70.9 & 51.2 & 56.4 & 34.9 \\
\hline
\end{tabular}


Graph Of Violence Over Women In West Bengal\& India: The Possible Way

\begin{tabular}{|c|c|c|c|c|c|c|c|c|c|c|c|}
\hline Bihar & 2.8 & $\begin{array}{lll}8 & 8 & 0 \\
\end{array}$ & 10.5 & 921 & 7 & 1 & 452 & 60.3 & 35.6 & 47.7 & 18.8 \\
\hline Gujarat & 2.2 & $\begin{array}{lll}2 & 5 & 8\end{array}$ & 37.4 & 92 & 6 & 1 & $\begin{array}{ll}1 & 0\end{array}$ & 80.5 & 58.6 & 55.0 & \\
\hline Haryana & 2.8 & $\begin{array}{lll}4 & 4 & 7 \\
\end{array}$ & 29.0 & 861 & 6 & 8 & 103 & 79.3 & 56.3 & 50.5 & 27.3 \\
\hline Karmataka & 1.7 & 275 & 34.0 & 964 & 5 & 3 & 195 & 76.3 & 57.5 & 56.9 & 31.9 \\
\hline Kerala & 0.9 & $\begin{array}{lll}8 & 1 & 9 \\
\end{array}$ & 26.0 & 1058 & 1 & 4 & 198 & 94.2 & 87.9 & 50.4 & 15.3 \\
\hline $\begin{array}{l}\text { Madhya } \\
\text { Pra } \\
\text { des } \\
\text { h }\end{array}$ & 2.4 & 196 & 26.7 & 920 & 9 & 7 & 498 & 76.8 & 50.3 & 51.6 & 33.1 \\
\hline Maharashtitia & 2.3 & $\begin{array}{|lll|}3 & 1 & 4 \\
\end{array}$ & 42.4 & 922 & 4 & 8 & 135 & 86.3 & 67.5 & 53.5 & 32.6 \\
\hline Orissa & 1.6 & 236 & 15.0 & 972 & 9 & 6 & $\begin{array}{ll}9 & 7\end{array}$ & 76 & 51.0 & 52.8 & 24.6 \\
\hline Punjab & 2 & 482 & & 874 & 5 & 1 & 367 & 75.6 & 63.6 & 54.1 & 18.7 \\
\hline \multirow[t]{2}{*}{ State } & \multirow{2}{*}{$\begin{array}{c}\text { Population } \\
\text { Gro } \\
\text { wth } \\
\% \\
\text { P.A. } \\
1991 \\
-201\end{array}$} & \multirow{2}{*}{$\begin{array}{c}\text { Population } \\
\text { Densit } \\
\mathbf{y} \\
\mathbf{S q} \\
\mathbf{K m} \\
\mathbf{2 0 0 1}\end{array}$} & \multirow{2}{*}{$\begin{array}{c}\text { Urban } \\
\text { Popul } \\
\text { ation } \\
\% \\
2001\end{array}$} & \multirow{2}{*}{$\begin{array}{c}\text { S e } x \\
\text { Rati } \\
\text { o } \\
\%\end{array}$} & \multirow{2}{*}{\multicolumn{2}{|c|}{$\begin{array}{c}\text { Infant } \\
\text { Mort } \\
\text { ality } \\
\text { Rate } \\
1996\end{array}$}} & \multirow{2}{*}{$\begin{array}{l}\text { Maternal } \\
\text { Mort } \\
\text { ality } \\
\text { Rate } \\
1998\end{array}$} & \multicolumn{2}{|c|}{$\begin{array}{c}\text { L i t e r a t e } \\
\text { Population } \\
\% 2001\end{array}$} & \multicolumn{2}{|c|}{ Working Population \% 2001} \\
\hline & & & & & & & & Men & Women & Men & Women \\
\hline Rajasthan & 2.8 & 165 & 23.4 & 922 & 8 & 5 & 199 & 76.5 & 44.3 & 50.1 & 33.5 \\
\hline Tamil Iadu & 1.1 & $\begin{array}{lll}4 & 7 & 8 \\
\end{array}$ & 43.9 & 986 & 5 & 3 & & 82.3 & 64.6 & 58.1 & 31.3 \\
\hline That Pradesh & 2.6 & $\begin{array}{lll}6 & 8 & 9 \\
\end{array}$ & 20.8 & 898 & 8 & 5 & 7007 & 70.2 & 43.0 & 47.3 & 16.3 \\
\hline West Bengel & 1.8 & $\begin{array}{lll}9 & 0 & 4 \\
\end{array}$ & 28.0 & 934 & 5 & 5 & 266 & 77.6 & 60.2 & 54.2 & 18.1 \\
\hline All India & 2.1 & $\begin{array}{lll}3 & 2 & 4\end{array}$ & 27.8 & 933 & 7 & 2 & 407 & 75.6 & 54.2 & 51.9 & 25.7 \\
\hline
\end{tabular}

Note: Working Population Is The Total Of Main And Marginal Workers; Maternal Mortality Rate Is Per One Lakh Live Births.

[Source: Columns 2-5 \& 8-11: COI, Provisional Population Tables : 2001. Columns 6 \& 7: COI, Men And Women In India 2000, Tables 16 \& 19(B)]

From The Table 1 We Can See That The Population Density Of West Bengal Is 904 Per Square Kilometer In 2001 Which Is Quite High In Comparison With India. West Bengal's Population Growth Rate During 1991-2001 Has Been 1.8 Per Cent Per Year, Lower Than The All-India Annual Growth Of Rate Of 2.1 Per Cent. Similarly, Levels Of Infant Mortality, Maternal Mortality And Total Fertility Are Also Well Below The Respective National Averages. However, Though The State's Female Literacy Rate At 60 Per Cent Is Appreciably Higher Than The All-India Proportion Of 54 Percent, Its Worker-Population Ratio For Women At 18 Per Cent Is Substantially Lower Than The All-India Figure Of About 26 Per Cent.

In Terms Of Personal Security, West Bengal Is Generally Considered To Be A Comparatively Safe State In The All-India Context. In 2001, For Example, The Number Of Cognizable Crimes Per One Lakh Population In West Bengal (76.7) Was Less Than Half Of The All India Average (172.3), With Only Meghalaya And Mizoram Reporting A Lower Rate.1 But Here Our Chief Concern Is One Crucial Component Of The Total Security Scenario In Any Civilized Society; Violence Against Women.

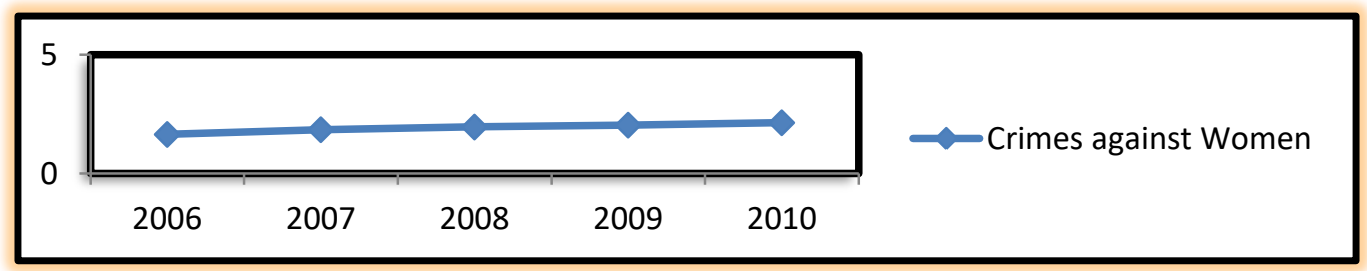

Perhaps The Most Painful Devaluation Of Women Is The Physical And Psychological Violence. It Can Scar The Early Life Of A Woman In The Shape Of Child Abuse, Incest And Sexual Harassment; It Can Threaten Marriage And Domestic Life, Sometimes Culminating In Murder Or Suicide, As So Tragically Evident In The Rising Number Of Such Atrocities Recorded In Crime Statistics.

There Are Several Different Types Of Crimes Over Women (CAW) Happening Every Second With Women Within Or Outside Of Home. 
* Outside Of Home:

- Anywhere Outside:

1. Rape On Women War Victims/Gang Rape/Rape \& Murder

2. Forced Prostitution/Women Trafficking

3. Acid Attacks

4. Forced Sex Of Girl-Child/Sexual Abuse

5. Molestation In Public Place

6. Abuse Of Widows/Divorcee/Any Girl-Child/Ladies

7. Kidnapping/Abduction

8. Eve-Teasing

9. Importation Of Girls Below 21 Years

10. Torture

11. Attempts To Murder/Homicide

12. Encouragement In Suicide/Suicidal Attempts

- Work Place:

1. Workplace Harassment Based On Sex Division

2. Molestation

3. Sexual Assaults

4. Use Of Filthy Languages

5. Sexual Aggression/Violence

6. Unwanted Sexual Indications Or Gestures

7. Unnecessary Sexual Advancement

8. Unnecessary Comments On Female Body Parts

9. Threat Of Rape

10. Spreading Of Sexual Comments/Videos/Mms/Sms

* Inside Home:

- By Family Members/In-Laws:

1. Honor Killings

2. Dowry Deaths

3. Domestic Violence

4. Using Filthy Languages

5. Physical/Mental/Psychological/Economical Tortures

6. Denial Of Giving Plenty Of Food/Medicine/Education

7. Forced Sex/Rape/Sexual Harassment/Sexual Abuse By Family Members

8. Violence In Pregnancy

9. Female Genital Mutilation

10. Female Infanticide

11. Forced Abortion Of Unwanted Child

12. Gender Discrimination Among Male And Female Child

- Bylife Partner/Spouse/Husband:

1. Physical/Mental/Economical/Psychological Tortures

2. Domestic Violence

3. Dowry Deaths

4. Violence In Pregnancy

5. Female Genital Mutilation

6. Female Infanticide

7. Marital Rape

8. Use Of Filthy Languages

9. Forceful Unwanted Abortion

10. Forced Sex With Anyone Else

However Let Us Focus On The Fact That The Crimes Against Women Under The Indian Penal Code Are As Follows:

1. Rape (Sec. 376 IPC)

2. Kidnapping And Abduction For Different Purposes (Sec. 363-373 IPC)

3. Homicide For Dowry, Dowry Deaths Or Their Attempts (Sec. 302/304B IPC)

4. Torture/Cruelty: Both Physical And Mental (Sec. 498A IPC)

5. Molestation (Sec. 354 IPC) 
6. Sexual Harassment/Eve-Teasing (Sec. 509 Or 294 IPC)

7. Importation Of Girls Up To 21 Years Of Age (Sec. 366B IPC)

Let Us See The Percentage Of Crimes Against Women (CAW) Of West Bengal In Comparison Of India. If We Look At The Information Released By The National Crime Records Bureau For 2002, It Would Be Clear That Torture Or Cruelty Tends To Account For The Highest Share In Total CAW In The State; More Than Half In 2002 As Against Less Than One-Third For All-India ; In The Same Year; Rape Accounted For 10 Percent Of Total CAW Here As Against 11 Per Cent Of All Over India Total CAW; Molestation Constituted 11 Per Cent Of The West Bengal Total CAW While In All-India CAW This Proportion Was More Than Double At 23 Per Cent. The Following Two Charts Illustrate The Relative Shares Of Each Of The Seven Listed Categories Of CAW In Total CAW; Chart V I With Respect To In West Bengal And Chart V II With Respect To All India.

Chart 2: Percentage Share Of CAW In West Bengal In 2002

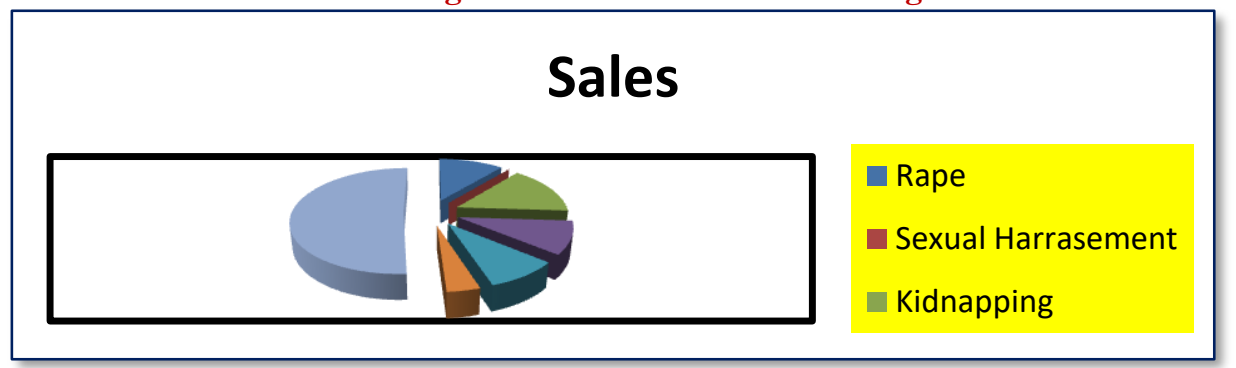

Source: NCRB, Crime In India 2002

Chart 3: Percentage Share Of CAW In West Bengal In 2002

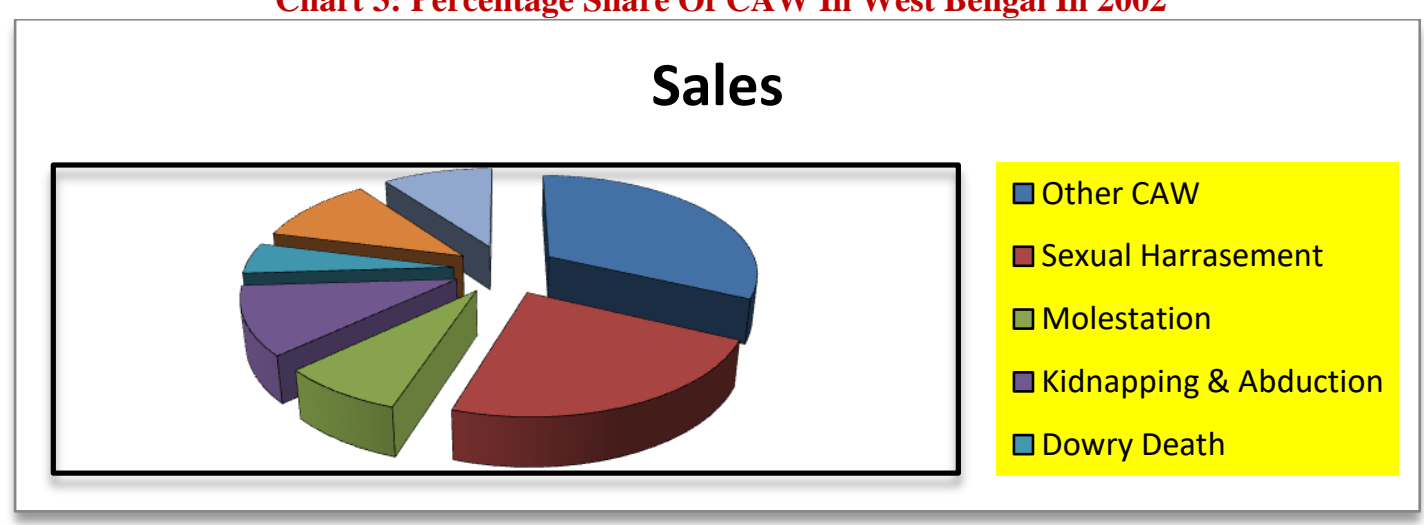

Source: NCRB, Crime In India 2002

In The Table 2 We Can Discover The Incidence And Rate Of Crimes Against Women (CAW) In West Bengal And All-India (2001-2003). Table 2 Provides Crime Figures Relating To Incidence Of CAW For The Years 2000-2003 And Also The Rate Of CAW Per One Lakh Population In West Bengal And India In 2001, As These Rates Indicates A More Realistic Comparative Picture Of Crime. It Will Be Seen That West Bengal Is Better Situated As Compared To All-India, With Respect To The Rates For Total CAW (8.2 Per Lakh Population), As Well As Individual Components Of CAW (Except Dowry Death, Which Is On Par With All Over India).It Will Also Be Seen In Table V 3 That West Bengal's Share Of The All-India Incidence Of Rape, Dowry Death And Total CAW Has Remained Below The State's Share In The All-India Population (Roughly 8 Per Cent).Surprisingly, However, CAW As Proportion Of Total IPC Crimes In The State (9-11 Per Cent) Has Remained Higher Than The Comparable All-India Figures (6-8 Per Cent).

Table 2 Incidence And Rate Of Crime Against Women (CAW) In West Bengal And All-India: 2001-2003

\begin{tabular}{|c|c|c|c|c|c|c|c|c|c|c|}
\hline & \multicolumn{6}{|c|}{ Incident Of CA In West Bengal } & \multicolumn{4}{|c|}{ Rate Of CA W In 2001} \\
\hline & 2 & $\mathbf{0}$ & $\mathbf{0}$ & 1 & 2002 & 2003 & $\mathbf{W}$ e $\mathbf{s}$ & B e n g a l & & n d i a \\
\hline Murder (Sec 498A, 302 IPC) & 1 & & 2 & 8 & 141 & 115 & & - & & - \\
\hline Culpable Homicide (304 IPC) & 3 & & & 0 & 33 & 25 & & - & & - \\
\hline Dowry Death (304B IPC) & 3 & & 1 & 9 & 263 & 313 & 0 & 3 & 0 & . \\
\hline
\end{tabular}


Graph Of Violence Over Women In West Bengal\& India: The Possible Way

\begin{tabular}{|c|c|c|c|c|c|c|c|c|c|c|}
\hline Abetment To Suicidel Sect 498_A306 IPC) & 8 & & & 5 & 927 & 820 & & & & - \\
\hline 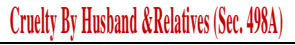 & 3 & 6 & 5 & 4 & 3823 & 4727 & 4 & 8 & 4 & . \\
\hline Rape (376 IPC) & 6 & & & 6 & 723 & 969 & 0 & 9 & 1 & . \\
\hline 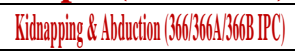 & 6 & & & 4 & 640 & 715 & 0 & 9 & 1 & . \\
\hline Molestation (354 IPC) & 7 & & & 8 & 800 & 1018 & 1 & 2 & 3 & . \\
\hline 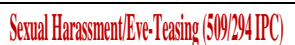 & 1 & & & 1 & 7 & 14 & 0 & 1 & 0 & . \\
\hline Total CAW (Crimes Against Women) & 7 & 1 & 4 & 5 & 7357 & 8716 & 8 & 2 & & 4 \\
\hline
\end{tabular}

[Source: NCRB, Crime In India 2001 And Memo Of Jt. Secretary, Dept Of WCD And Socialwelfare, GOWB, To The National Commission For Women, Date 25.05.2004]

The Magnitudes Of Various Types Of Officially Recorded Crimes Committed Against Women (CAW) Can Provide A Rough Index Of Violence Against Women, Especially When These Are Assessed In The Context Of Population Growth; But It Must Be Remembered That Only A Fraction Of The Actual Prevalence Of Crime Is Captured In These Statistics. Additionally, There Are Certain Gender-Oriented Laws Under Which Crime Statistics Are Recorded As SLL (Special And Local Laws) Crimes; Such As Immoral Trafficking Prevention Act Of 1956; Dowry Prohibition Act Of 1961; Child Marriage Restraint (Amendment)Act Of 1979 And Commission Of Sati (Prevention)Act Of 1986.

Table 3 Indicators Of CAW In West Bengal: 1995-2002

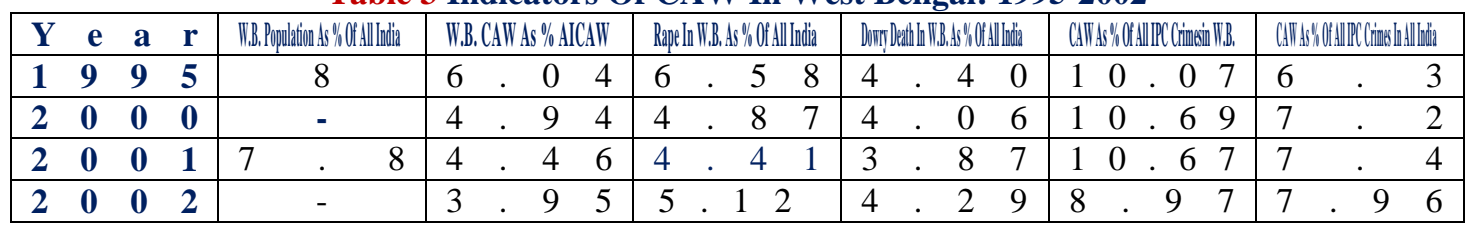

[Source: Calculated From Relevant Tables In NCRB, Crime In India, 1995, 2000, 2001, 2002]

From This Above Table 3 It Is Quite Clear That From The Years 1995 To 2002 The Crimes Against Women Are Disturbing. In 1995 The Ratio Of Crimes Against Women In Comparison With All India Crimes Against Women Was 6.04; In 2001 It Was 4.94; In 2001 It Was 4.46 While In 2002 The Crimes Against Women Was 3.95. From Here We Can Say That The Rate Of Crimes Is Actually Degrading But It Is To Be Noted That All Incidents Were Not Noted Down As It Was Condemned By The Society. The Ratio Of Rape In West Bengal In 1995 In Comparison With India Was 6.58; In 2000 It Was 4.87; In 2001 It Was 4.41 While In 2002 The Rate Of Rape In West Bengal Was 5.2. The Rate Of Dowry Death In 1995 In Comparison With 1995 Was 4.40; In 2000 It Was 4.06; In 2001 It Was 3.87; While In 2002 The Rate Of Dowry Death Was 4.29 In Comparison With Entire India. These Two Ratios Are Certainly Alarming As The Rate Of Rape And Dowry Death Is Still Increasing. However The Crimes Against Women Are Decreasing From 10.07 To 8.97 From 1995 To 2002 In Comparison With India Where The Crimes Against Women Are Increasing Gradually From 6.3 To 7.96 From 1995 To 2002. Among All Offences Perpetrated Against Women, The Most Heinous Are The Crimes Of Rape And Dowry Death. The Rape Cripples A Woman Mentally And Hurts Her Physically Beyond The Imagination Of Anyone. It Has Several Other Forms, Like Gang-Rape, Marital Rape Etc. Gang Rape Is The Brutal Inhuman Physical And Sexual Torture Over A Woman By A Group Of Men. It Also Cripples Her SelfConfidence And The Rest Is Nested Upon The Society. Marital Rape Is The Nastiest Kind Of Rape Where The Woman Is Raped By Her Spouse. Even Though Marriage Is Thought To Be The Most Sacred In Nature But In Today's World Many Husbands Think It Is Their Primary Right To Commit Sexual Torture Over Their Life Partners. Dowry Death, On The Other Hand, Arises Out Of A Mentality That Denies The Woman Equal Status And Respect Even In Supposedly Own House.In India Most Families Are Suffering From The Threat Of Dowry Death. Dowry Has Also Begun To Make Its Appearance Among The Tribal And Muslim Communities Of West Bengal. The Sexual Comments At Workplace Also Try To Dominate The Freedom Of The Woman And To Control Her Professional Advancement. In Today's India The Torture Of Women Become A Growing Threat Everywhere Whether It Is In India Or In West Bengal.

\section{CONCLUSION}

From These Above Mentioned Graphs It Is Clear That Women Are Safe Nowhere. Workplace Harassments Are Prevalent In Most Workplaces Of India As Well As Of West Bengal. Domestic Violence Is Also Existent Everywhere. Marital Rape, Gang-Rape, Rape, Acid Attacks Are Also There In Their Notorious Forms. All Of Them Are Equally Nasty In Nature Where Main Intention Is To Shun The Progress Of A Woman And To Stop Her Professional Growth. All Of Them Hamper The Women Mentally And Socially While Ending 
Or Nearing To End Their Self-Confidence Level. That Type Of Women Becomes Afraid Of Life And Some Of Them At The Weakest Moment Even Commit Suicide. We Have To Make Our Penal Code So Strong That No Culprit Can Escape Punishment By Misusing Their Monetary Power. The Police And Judicial System Has To Be Sympathetic To The Suffered Women.The Doctors Should Have Empathy On Their Conditions. Unfortunately That Sympathy Is Lacked Even In This Twenty-First Century. Our Legal And Administrative Systems Of West Bengal Is Yet To Corporate With The Girls. Workplace Harassment Should Be Dealt Carefully. Even The Verbal Application Of Assault Made By The Girl Is To Be Treated As FIR By The Police System Of West Bengal. The Assaulters Should Not Escape The Criminal Penalty At Any Cost. We Should Not Treat Our Girls To Stay Within The Home But To Educate Our Boys To Respect Girls As Equal Sex. The Strictness Of Punishment Cannot Ensure The Security Of Women But A Slight Change Of Attitude Towards Them. Charity Begins In Home And Hence We Have To Begin To Educate Our Boys To Respect Girls Right Now. Only Then The Women Could Feel Free To Enjoy Their Freedom. This Is The Only Possible Way-Out From This Breathtaking Situation.

\section{REFERENCES}

[1]. Mukherjee, Mukul (2004). Asituationalanalysisofwomenandgirlsinwestbengal. New Delhi: National Commission For Women.

[2]. Beauvoir, Simon De (2010). Thesecondsex. New York: Vintage Books.

[3]. Government Of India (GOI), Ministry Of HRD, Selected Educational Statistics 2000-2001.

[4]. GOI (2001-2002).Ministryofhumanresourcedevelopment (HRD):Annualreport: 2001-2002.

[5]. GOI

(1997).Ministryofhumanresourcedevelopment:Departmentofwomenandchilddevelopment:Statisticalprofil eofwomeninindia: 1997.

[6]. Aasha Kapur Mehta (26 October 1996).Recastingindicesfordevelopingcountries: A Genderempowermentmeasure. EPW.

[7]. Anandabazar (Bangla Newspaper), 4 August 2004

[8]. Arnold, F., Parveen Nangia And Umesh Kapil (14 February 2004). Indicatorsofnutritionofwomenandchildren. EPW.

[9]. Banerjee, Nirmala And Poulomi Roy (2004).Genderinfiscalpolicy: Thecaseofwestbengal, New Delhi: The United Nations Development Fund For Women.

[10]. Bose, Ashis (19May 2001). Censusofindiaandafter. EPW.

[11]. Census Of India (COI) (2001).Provisionalpopulationtotals. West Bengal.

[12]. Chatterjee, Biswajit And Dilip Ghosh (2001).Insearchofa Districtdevelopmentindex.Nadia: State Institute Of Panchayat And Rural Development, Kalyani.

[13]. Chen, Marty And Jan Dreze (30 September 1995). Recentresearchonwidowsinindia. EPW.

[14]. Choudhuri, Sukanta, (Ed) (1990). The Living City Vol. II.Calcutta: OUP.

[15]. Ghatak, Maitreya And Maitreesh Ghatak (1 May 2002). Recentreformsinwestbengal: Towardsgreaterparticipatorygovernance?. West Bengal: EPW.

[16]. Gopalan, Sarala (2002). Towardsequality-Theunfinishedagenda-Statusofwomeninindia2001.New Delhi: National Commission For Women.

[17]. Ghosh, Jeeja (2003). Services For Girls And Young Women With Disabilities In Kolkata. Kolkata.

[18]. Indianjournaloflaboureconomics. Vol. 45(1), January-March 2002.

[19]. Jasodhara Bagchi."Women In Calcutta". In Sukanta Choudhuri (Ed) (1990). Thelivingcity. Vol. II, Calcutta: OUP. (P.49).

[20]. Kishore, Sunita And Kamala Gupta (14 February 2004). Women'sEmpowermentinIndiaandtheStates: Evidencefromnfhs. EPW.

[21]. Mazumdar, Vina (Ed) (2000). Duiprithibiruttaran. Kolkata.

[22]. Mehendale, Leela (8 January 2001). Crime, Womenandjusticedelivery: Thesystemspeaks. Ainstream.

[23]. West Bengal Commission For Women (WBWC) (2002).Sexualviolenceagainstwomen.Kolkata: WBWC.

[24]. National Crime Records Bureau (NCRB).Crimeinindia.Relevant Years.

[25]. Premi, Mahendra K. (26 May 2001). Themissinggirlchild. Economic And Political Weekly (EPW).

[26]. Satish Balram Agnihotri (2000). Sexratiopatternsintheindianpopulation: Afreshexploration. New Delhi.

[27]. WBCW (2004). Thechallengeahead: Changingstatusofwomeninwestbengal: 1970-2000: Anexecutivesummary. Kolkata. 